УДК 22.01(227.2)

DOI https://doi.org/10.30970/2307-1664.2019.25.15

\title{
HOLY SPIRIT, SPIRITUAL GIFTS AND UNITY OF THE CHURCH: HERMENEUTIC-EXEGETICAL EXCURSION INTO THE FIRST EPISTLE OF THE APOSTLE PAUL TO THE CORINTHIANS 12-14
}

\author{
Oleksandr Shumilin \\ Bishkek Bible College \\ Tverskaya str., 42, 720080, Bishkek, Kyrgyzstan
}

The article is devoted to the hermeneutic-exegetical study of 12-14 chapters of 1 Epistle of the Apostle Paul to the Corinthians. It is these chapters that tell about one of the reasons for the separation in the Corinthian community: different understanding by the community members of the purpose and use of spiritual gifts in the church, especially the gift of tongues, as well as pride and exaltation. In the same chapters, the reader finds a way to achieve unity. The principle of the indivisibility of the church of God is shown, which the author of the Epistle likens to the human body. In it, all members are equal, each fulfills its role and serves not so much to itself as to the whole body. Organs invisible to the eye are sometimes much more important than visible ones.

As a result of research, the source of spiritual gifts was determined, who and how received spiritual gifts was revealed, the purpose of spiritual gifts was revealed, the main conditions for the use of gifts were determined. It is shown that love and the desire to edify the church with their ministry with the help of spiritual gifts are those qualities of a Christian that are in the first place. The Corinthians and modern Christians correctly understanding 12-14 chapters of the epistle and putting into practice the spiritual truths set forth in them will serve to maintain unity in the local community and achieve unity between representatives of different Christian faiths.

There are quite a few works devoted to the theme of church unity. To a greater extent, the researchers took as a basis either other chapters of 1 Corinthians or other books of the Bible. A distinctive feature of this work is its emphasis on the above chapters of the Epistle to the Corinthians, revealing the role of the Holy Spirit in the distribution of spiritual gifts and building the unity of the church.

Key words: Holy Spirit, spiritual gifts, unity of the church, appointment of spiritual gifts, use of spiritual gifts, gift of tongues.

The first Epistle to the Corinthians was written by the apostle Paul at Ephesus (1Cor.16:8) in the middle of the 1 st century. One of the motives that prompted him to write a letter to Corinth is the experience of separation in the church (1:10-12). Among the many reasons that split the church are a different understanding by community members of the topic and the practice of spiritual gifts. Be in Corinth, Paul, possessing the gift of discerning spirits (Acts 16), could identify God's and false gifts of other languages [1, p. 5-6] and solve the problem locally. However, being far from Corinth, he gives fundamental principles that help the believers of this community to receive the correct knowledge of spiritual gifts and instructions on how to use them.

The apostle touches upon such issues as: giving members of the community spiritual gifts, attitudes towards gifts, assigning gifts, distributing and using gifts in the church, and the most important conditions for using gifts.

God endows every born-again Christian with spiritual gifts (12:1-30)

Starting the theme of spiritual gifts and ministries in the church, the apostle Paul immediately puts emphasis on the importance of God's guidance in the life of every Christian. He

(c) O. Shumilin, 2019 
divides the life of each person into two stages: before turning to Christ (those who do not believe in Christ, the apostle calls the Gentiles) and after. At the first stage of life, all people are driven by mute idols (in chapter 10 they are called demons) and often do what they would not want (12:1-2). But after accepting Christ as a personal Savior, their life should not be guided by their own will, but by the will of their creator. God has a plan for everyone. The Holy Spirit endows everyone with spiritual gifts (12:4). Jesus Christ, as head of the Church, entrusts the ministry $(12: 5)$. God the Father empowers (12:6).

Gifts and services are given to each, each especially, for the benefit, as God pleases (12:711). All gifts are important, just as in the human body all organs (members) are important 12:14-27. Paul deliberately uses the type of the body so that the Corinthians clearly understand the important spiritual truth. The body is made up of members. Together, the members make up one body. Organs invisible to humans (obviously, heart, liver, etc.) are sometimes much more important than visible ones. Obviously, the members of the body do not have the question of their insignificance and imperfection or their superiority and exclusivity. For them, it is "important" that they are in the body and can serve each other. Moreover, each member serves not so much to himself as to the whole body. Paul sees the desire of man, by virtue of perversity, to have a visible, bright gift. And therefore, he says that a ministry invisible to other people often brings more benefits. Important is the assertion that the body cannot consist of one member and that, being one member, one cannot be another at the same time. The rhetorical question (12:28-30) confirms this truth.

The use of the gifts in the church (12:31-14:40)

\section{Attitude towards the gifts}

We have stated earlier that the administration of spiritual gifts belongs to the Holy Spirit. How should the members of the Body of Christ treat these gifts?

Undoubtedly, each received gift must be treated thankfully (see Eph.5:16, 18; Rom. 12:1-2), knowing that God does not make mistakes and that all things work together for good (Rom.8:28). How do we treat gifts, which we desire to possess but have not received them yet? It is no secret, believers hold different views on the subject. Some say that $\chi \alpha \rho 1 \sigma \mu \alpha \tau \alpha$ is a gift and it should not be asked from God: He knows what His children need. Others believe that we may boldly ask it from God. Why so many opinions that cause divisions in churches and among churches? The problem is that there are many interpretations of a few particular passages of Scripture.

Let us look at 1 Cor. 12:31; 14:1 and 14:39 first. The key word here is $\zeta \eta \lambda$ ov $\tau \varepsilon$ (Imperative, Active). In a positive sense it means 1) to strive, to desire, to exert oneself earnestly [2, p. 338] and 2) to set one's heart on, to have deep concern for [3]. Paul encourages the Corinthians to seek spiritual gifts. What does it mean? Bengel provides a short clear answer, "Believers may dream of a gift; the Spirit administers gifts as He wishes" [4, p. 601].

\section{The purpose of gifts and ministries}

Paul, in the first place, points out that ministries and gifts are given by Christ and the Holy Spirit so that believers take care one for another (12:25). Ministries and gifts are not a reward, but God's grace. They are not given to believers so that they might feel superior to other members of the Body or count on more attention and honor if they possess outward gifts of the Spirit. God grants His gifts so that Christians might minister with them to each other (cf. 1Pe.4:10). Metonymy, employed by Paul, shows this truth in the best way possible. Not a single part of a human body ever thought that it was better than others were. It never considered whether the rest of parts were needed at all. Each member needs others and cannot afford being independent. It is dead without other members. "In a healthy human body different parts cooperate with each other and even 
partly substitute one for another in case of crisis" [5, p. 130]. Some interior organs are much more vital. Their dysfunction inevitably leads to death [6, p. 420], while "a man who lost his eye, arm, or leg can still live" [7, p. 221]. Understanding of the significance of each member of the Body "was missing in Corinth where powerful members acted regardless of everything and paraded their "freedom" whereas particularly gifted lived by their self-esteem. Now the church needed to go back to love that builds up" [7, p. 222]. MacDonald writes: "Mutual care prevents divisions in the body. One gives another whatever he needs and receives such help back that only another member is able to provide. That is how it should work in Church. An exaggerated attention towards one gift of the Spirit will result in conflict and contentions" [8, p. 885].

Second, a Christian is called to praise God through his ministries and gifts. Paul writes,

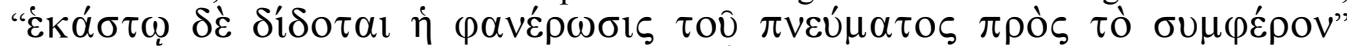
(1Cor.12:7). The main meaning of the word $\varphi \alpha v \dot{\varepsilon} \rho \omega \sigma \iota \zeta$ (bringing to light, disclosure) is to make something known, clear, and obvious $[6,384]$. For example, the word $\varphi \alpha v \varepsilon \rho \omega \psi \eta '$ Jesus uses to demonstrate that nothing can be concealed; at some time it will be revealed. In 2 Tim. 1:10 the word $\varphi \alpha v \varepsilon \rho \omega \psi \varepsilon i \sigma \alpha \nu$ is used as "revealed" grace. The word $\varphi \alpha \vee \varepsilon \rho \omega \sigma \varepsilon l$ Paul employs in 1Cor.4:5, when he talks about disclosure of the counsels of the hearts by God as well as in 2Cor.4:2, when he speaks about revelation of truth to men. In 1Cor.12:7 the apostle also uses this word to demonstrate the task of spiritual gifts: "do it so that because of them the Holy Spirit becomes known, clear, and obvious in the Church and worldwide" [6, p. 384-385].

Third, gifts are designed to make the Gospel accessible for people (1Cor.2:5). Due to this gift alone, which assisted Paul in ministry (Rom.15:16), the apostle could have reached many nations with the Good News.

\section{Administration and the Use of Gifts in the Church}

Paul draws the attention of the Corinthians to a number of important truths.

First, spiritual gifts are given to every believer, not chosen members only ( $\dot{\varepsilon} \kappa \alpha \dot{\alpha} \sigma \omega)$ ) "There are no Christians left without some kind of ministry" [8, p. 882]. History demonstrates numerous examples when church authorities took all responsibilities upon themselves, and, as a result, the gifts of church members were left unclaimed [7, p. 213]. In such situations, the Church as the Body of Christ could not function normally. It became disproportional. The leaders in charge committed themselves to ministries they actually could not carry out since they lacked necessary gifts. Laymen, on the contrary, became spiritually weak since they had no opportunities to practice their gifts.

Second, Christians are provided with gifts and ministries for their benefit. The word

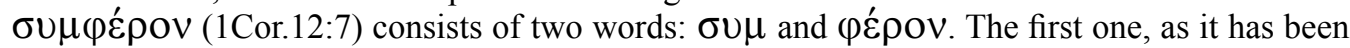
mentioned above, generates the meaning of accompaniment, correlation, and participation in compound words. The second is used as "bring, carry, and produce". Literally, it means, "bring together". This word is also used in the meaning of "help, produce profit". Thus, we can say that gifts and ministries are given to the community for their mutual benefit.

Third, gifts and ministries are distributed among Christians as the Holy Spirit wills (ßoú $\lambda \varepsilon \tau \alpha \mathrm{l})(12: 11,18)$. The Holy Spirit has His own plans and intentions concerning each member of the Body. That is why every believer must gratefully receive any gift from God since he knows that all things work together for good (Rom.8:28).

\section{The most important conditions for the use of gifts}

1. Love is one of the most important conditions for the use of gifts and carrying out of entrusted ministries. Hodge writes: " $<\ldots>$ Paul had taught $<\ldots>$ that love was of greater value than any gift" [9, p. 278]. Gaffin expresses the same thought [10, p. 586].

The passage 12:31-14:1 clearly demonstrates this while a chiasm (section A - 12:31; section $\mathrm{B}-13: 1-13$; section A1 - 14:1) highlights this truth. 
Paul employs a number of practical examples in order to show the necessity of love by applying those examples also to himself (for this he uses human-readable images). It implies that all Christians including the apostles need love not just individual believers in Corinth. If a Christian speaks with the tongues of men and of angels, and has not love, he becomes as an icy cold metal that freezes one's body and soul. If a Christian speaks beautifully, and has no love, he does not draw people to himself, he pushes them away. People consider him a hypocrite.

Though a Christian has the gift of prophecy from God, and understands all mysteries, and though he has all faith, so that he could remove mountains, but has no love, he and his ministry are nothing. If a Christian is ready to sacrifice his goods and give his body to be burned, and has not love, he will not benefit from it. On the contrary, he will be seen as an irrational fanatic.

Later in the chapter (13:4-7) Paul portrays a true love which is expressed through deeds not words, such love that the Corinthians lacked.

Hodge pointed out that the Corinthians were impatient, unsatisfied, envious, arrogant, selfish, untactful, indifferent towards feelings and interests of others, suspicious, susceptible, and quick to judge. That is why the apostle contrasts their condition with signs of true love $[8$, p. 888$]$.

Love suffers long. The word $\mu \alpha \kappa \rho \circ \theta 0 \mu \varepsilon \mathrm{l}$ is most frequently used in the New Testament to denote delayed reaction to some actions. In Rom. 9:22, Paul applied it to demonstrate God's patience towards sinners destined to perish. Love is slow to react to evil conduct; it endures mocking and superciliousness. Love is kind. It shows love to others without bias. Love envies not. It is not jealous of somebody else's success, ministry, gifts, and conditions; "it feels joy when others are praised and exalted" [8, p. 888]. Love boasts not, it is not puffed up. It does exalt itself but ascribes all achievements to God not itself. Love does not behave itself unseemly (OỦ K $\hat{\alpha} \sigma \chi \eta \mu \mathrm{O} \varepsilon \hat{\imath})$. It is tactful, polite, and considerate. Love seeks not its own. Love does not seek profit; it desires to be caring and helpful to others. It is happy that others who possess outward gifts of the Spirit may serve the Lord with them. It understands that each member of the Body of Christ contributes to community life and praises his Savior. Love is not easily provoked. It is ready to endure scorns and insults. Love thinks no evil. It is not suspicious of others, it does not take revenge, and does not desire to do harm to those who are more successful. Love rejoices not in iniquity but rejoices in the truth. It does not enjoy somebody else's failures as most competitors do. Love is sympathetic. Being a part of community, love rejoices at any success. Love bears all things. It is quick to forgive and never puts flaws of others on display. Love believes all things and attempts to interpret deeds and actions in a positive light. Love hopes all things. It hopes that God will mold every person and accomplish His goals. Love endures all things. It endures mocking, arrogance, and enjoys everything the Lord has given it.

The passage from 1 Cor. 13:1-13 is obviously directed against such "exaltation" when striving for more effective gifts (prophecy, glossalalia, and knowledge) caused envy, arrogance, irritation, and other similar sins. Then the most important thing - love - was lost [11, p. 229-230].

2. The second necessary requirement for the ministry and the use of gifts is the benefit for each member and the Body of Christ as a whole. Paul reveals this truth as he compares the gift of tongues with the gift of prophecy. "For Paul the charismatic experience is characterized not only by exaltation and the depth of revelation (cf. 2 Cor. 12:2-4), but explicable words, which are uttered by a believer to edify and exhort one another (1 Cor. 14:3-5, 16-19, 24-25). <..> Whatever does not benefit others does no good to the church" [11, p. 230].

The gift of tongues in Corinth that some were pride of and others longed to acquire was useless to the Church unless the tongues are interpreted. In this case the gift should be exercised in "one's prayer room not in church" [12, p. 31]. Even though, Paul recommends an owner of the gift 
to ask also for the gift of interpretation in order to bear fruit both for the spirit and the mind (1Cor.14:14-15). A chiasm in verses 12-17 allows us to arrive at this conclusion.

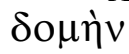

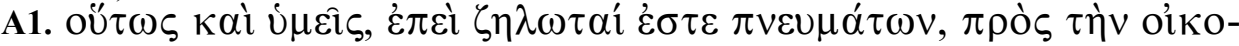

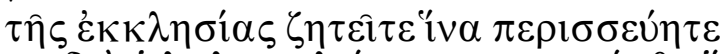

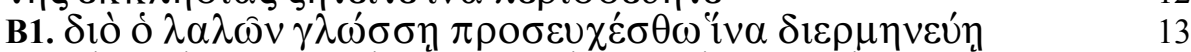

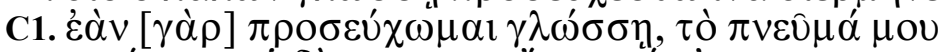

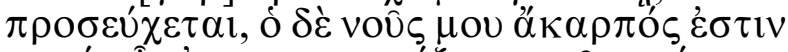

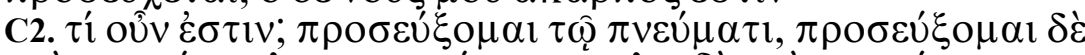

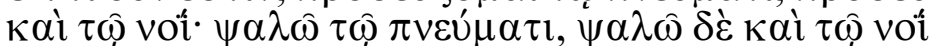

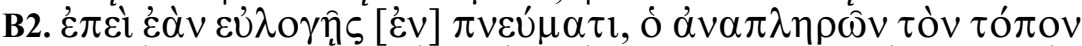

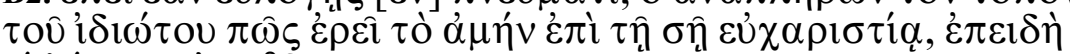

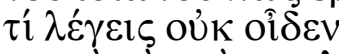

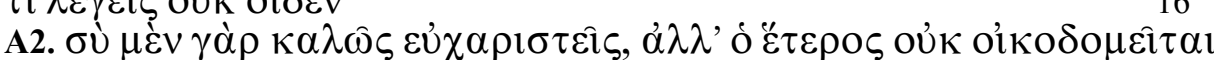

Verses 12-13, 16-17 speak about the edification of the church. Verses 14-15 urge those who possess the gift of tongues to pray for the gift of interpretation so that the whole church would be edified, not their mind only.

Verse 13 confirms our conclusion: a person praying in an unknown tongue should ask for the gift of interpretation of his own prayer. Apparently, it is important not only for edifying one's mind but probably for testing whether it was from God or not.

The gift of prophecy is most important for edification, exhortation, and comfort both for the whole church and individuals (1Cor.14:2-3). Paul urges the Corinthians to seek this kind of gift. One needs to notice, that any gift used for edification of the church is useful (14:26).

3. The third important condition is the necessity of God's guidance. Paul writes in 14:22,

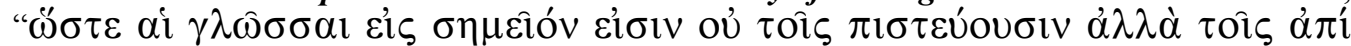

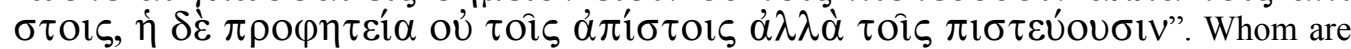
believers called to minister to with their gifts? Paul says that an unknown tongue is a sign for unbelievers. What does the word "sign" ( $\emptyset \eta \mu \varepsilon \hat{\imath o ́} v)$ mean? Who are considered unbelievers? There are several interpretations [9, p. 294-296]:

1) some employ the word $\sigma \eta \mu \varepsilon \hat{\imath}$ óv as mark or proof like in 2 Cor. 12:12 and conclude that "Tongues are a proof that those among whom they are used are not believers, but unbelievers". In this case $\sigma \eta \mu \varepsilon \hat{\imath o ́} \mathrm{~V}$ is a sign of, but not to or for;

2) others use the word $\sigma \eta \mu \varepsilon i o ́ v$ in the meaning of prodigy or wonder and believe that, "Tongues are a wonder designed not for the benefit of believers, but for unbelievers". However, such interpretation of the given verse contradicts 14:24;

3 ) the third use the word $\sigma \eta \mu \varepsilon i o ́ v$ as a sign of judgment on those who rejected faith in their stubbornness; MacArthur, as he studies 14:20-25 and Is.28:9-11, assumes that the gift of tongues was meant for Israel as a sign of condemnation for unbelief and rejection of Christ [6, p. 502]. Wiersbe holds to the same opinion [5, p. 142]. MacDonald goes further. He considers as unbelievers not only Israel, but all people, who rejected the Word of God and closed their hearts for the truth $[8$, p. $893 ; 13$, p. 566] gives a similar interpretation;

4) the fourth think that $\sigma \eta \mu \varepsilon i o ́ v$ must signify some indication to divine presence, and become a sign for those who are disobedient. Hodge holds the same opinion [9, p. 296]. He points out that one must not mix the phenomenon of signs and the gift of tongues. He gives an example of Israelites, "When Hebrews were disobedient God sent foreigners among them". 
It is hard to agree to the first two interpretations since they contradict the context. As for the fourth interpretation, it is difficult to conform to Hodge's opinion that the tongue as a sign must be distinguished from the tongue as a gift. The context of chapters 12-14 does not allow us to arrive at a similar conclusion. Paul keeps talking about gifts and a sudden shift from the term "gift" to the term "sign" is barely possible. Most likely, the gift of tongues is a sign in particular cases.

As for unbelievers, it seems that not only Israelites are meant, who rejected Christ, but also disobedient church members. The context and Paul's reference to a particular historical example from the Old Testament (Is.28:9-11; Deut.28:49) point to that. Israel's disobedience led to captivity and the dwelling among people speaking in a foreign language. Community prayers in other tongues without interpretation break the order. It condemns believers whose conduct demonstrates that they have departed from truth.

Paul employs a very interesting literary device, which helps him to show that believers who break God's will, in essence, become unbelievers, whereas unbelievers, when they turn to God, become believers. This truth grows to be more clear when the author says that prophecy is a sign for believers. However, prophecy caused unbelievers to turn to God (14:24-25). Yet, at the same time, when a believer ignores the prophecy, God rebukes him in an unknown tongue. This truth can be depicted as follows.

As we analyze the material given above, we can arrive at the conclusion that the Holy Spirit introduces a special means of communication with people, both believers and unbelievers. If believers keep the order established by God, then speaking and praying in tongues, provided there is interpretation present, are normal. In this case, both the church is edified and unbelievers (Jews), present at worship service, are rebuked. If church members do not keep God's rules, then speaking and praying in tongues without interpretation condemns believers. They should change something in their lives. Meanwhile, unbelievers, attending worship services, are not edified and tempted.

The correct reaction of believers and church leadership to God's actions, undoubtedly, will contribute to church unity.

4. Another important condition for the use of gifts is the necessity of keeping a specified order for ministering with gifts set by God (14:26-38). First, all gifts must work for the edification of the church. «How is it then, brethren? when ye come together, every one of you hath a psalm, hath a doctrine, hath a tongue, hath a revelation, hath an interpretation. Let all things be done unto edifying» (14:26). At first glance, this verse speaks more about the purpose of gifts. Nonetheless, a more detailed analysis helps us to see that he urges every church member, before he or she

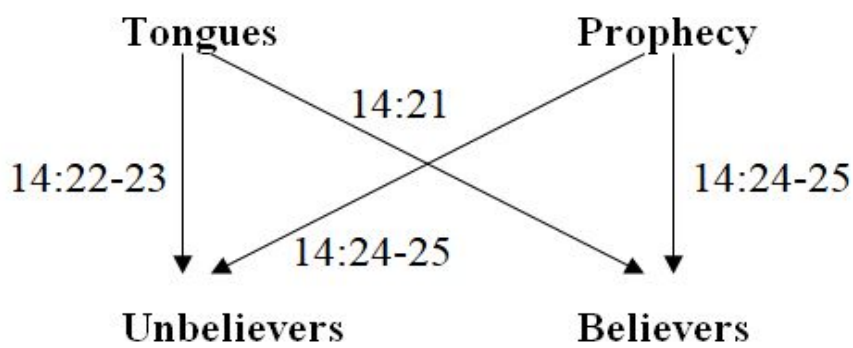

Рис. 1 
has begun to minister in the church, to think whether it edifies and builds up the whole church. The word o'k אo $\delta$ iǹv (up building, strengthening, encouragement, building, structure) always stresses the idea of making and building up a community, rather than its destruction. Church leaders are fully responsible for believers' participation in worship service.

Second, the leaders should not overload worship services with excessive sermons, speaking in tongues (provided there is an interpreter); it must be structured in order to avoid confusion. Simultaneous prophesying and speaking in tongues are prohibited $(14: 27,30-31)$. "Tongues were not to be exercised unless an interpreter was present. And at the most only three were to participate" $[14$, p. 1254]. The negligence of set rules demonstrates the guidance of some other spirit, not the Spirit of God (14:32). Keeping God's rules, on the contrary, leads to peace and unity (14:33).

Third, the prophecies must be judged and tested (14:29). The verb $\delta 1 \alpha \kappa \rho \imath v \varepsilon \tau \omega \sigma \alpha v$ (imper.; pres.) Paul uses in another grammatical form in 1Cor.4:7, when he speaks about God who distinguishes between believers and other people, and in Rom. 14:23, where he talks about

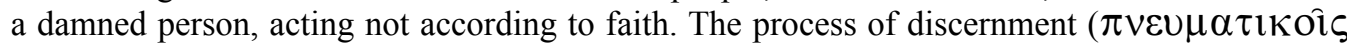

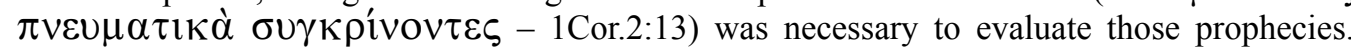
Compatibility of the prophecies with the apostolic tradition was an important criterion for their validity.

Dunn, as he speaks about criteria for validity, writes the following [11, p. 229]: "One of the criteria was kerygmatic traditions and legends about Jesus, which Paul communicated to converts, when they joined the church: those traditions in planted churches were some sort of constitution. These are the traditions Paul keeps referring to in his First Epistle to the Corinthians in order to solve debatable issues concerning "exalted" believers in Corinth (see especially 1 Cor. $9: 14,11: 23,12: 3,15: 3) .<\ldots>$ To Paul only such religious experience, which was consistent with foundational traditions, came from the Spirit. The Spirit of Christ must be in agreement with the Law of Christ (1 Cor. 9:21, Gal. 6:2)".

Fourth, women were not allowed to speak in church. In all important manuscripts such as $\wp^{46} \aleph$ A B $\Psi 0150024363381$ vs. 34-35 stand in this position, in some others, such as D F G, they follow 14:40. There are a number of interpretations concerning this verse. Some scholars argue that Paul prohibited women from "chatting", not teaching in church. MacDonald [8, p. 895] writes the following: "It is often claimed that in this verse Paul prohibited women from chatting and gossiping during worship service. However, this interpretation is incorrect. The word translated here as «speak» (lalei_n), had no meaning of «to chat» in Greek koine. The same word is applied to God in verse 21 of the given chapter and Heb. 1:1. It means, "speak authoritatively».

Other theologians, probably taking into consideration 1Cor.11:5, believe that women are not allowed to teach in church, except for special occasions when they are «under an extraordinary impulse of the Spirit». Verses 34-35 and the context dispute such interpretation. We may agree with MacArthur that women are not permitted to prophesy in church, nor in other places. Women, says MacArthur, are inevitably deluded when they usurp men's role [8, p. 515]. Paul suggested such order in others places beside Corinth. It was established in other churches $(14: 33,36)$ and was based not on apostle's words but God's commandments (14:37).

Verses 14:39-40 conclude the theme of gifts. Paul did not prohibit the Corinthians from speaking in tongues since he also had this gift (14:18). However, once again, he reminds of the advantages of prophesying and the necessity of keeping order in service "Let all things be done decently and in order".

As we conclude the theme of spiritual gifts, let us consider briefly the time of their operation and how they relate to us. These questions, which Paul touched on in his epistle, 
probably were not a serious problem for the Corinthians and the apostle just mentioned them casually. At present time this theme is a subject of theological debates. White interferes in one of the discussions between Gaffin and Grudem trying to restore the truth $[15$, p. $180-$ 181]. He comes to the conclusion that this passage (13:10) can not be a basis for solving this argument.

However, contemporary Christians find these questions challenging. How long should particular gifts operate in the Church? The passage from 1Cor.13:8-10 provides us with an answer.

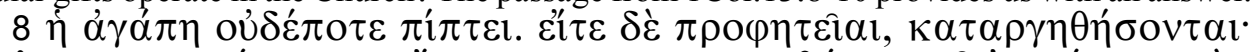

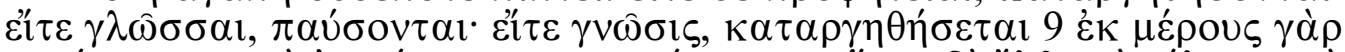

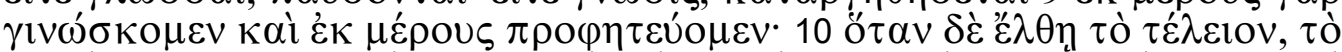

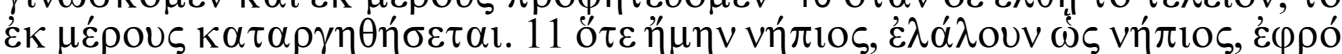

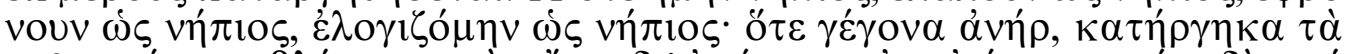

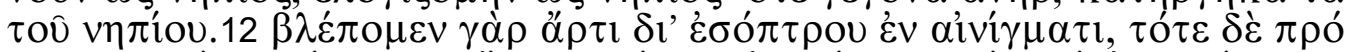

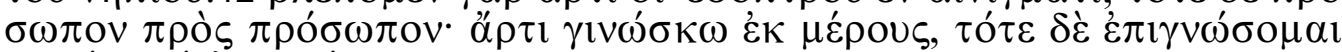
$\kappa \alpha \theta \omega \dot{s} \kappa \alpha i$ '̇ $\pi \varepsilon \gamma \nu \omega ́ \sigma \theta \eta v$.

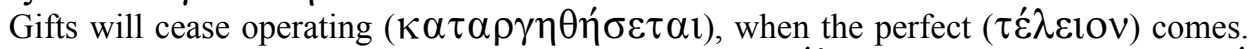
Nowadays there exist numerous interpretation of the word $\tau \dot{\varepsilon} \lambda \varepsilon$ lov. Some believe that $\tau \dot{\varepsilon}$ $\lambda \varepsilon$ lov is the time of the completion of the New Testament; others think it is the time of maturity; the third speak about the rapture of the Church; the fourth, like G. Fee, for example, suppose it is the Second coming of Christ [16,p. 646]. MacArthur states that $\tau \dot{\varepsilon} \lambda \varepsilon$ lo $V$ is none of the mentioned above; it pertains to eternity [6, p. 482]. We may agree with the three last interpretations to some extent: at some moment in time, all people of God will see Christ (13:12a). However, most likely, in this case the passage speaks about a personal encounter of every believer with Christ, since in verse $13: 12 \mathrm{~b}$ Paul talks about himself. Such interpretation is consistent with the context: it is important to keep in mind that the Corinthians longed to possess outward gifts of the Spirit. After believers have met Christ, they will not need them.

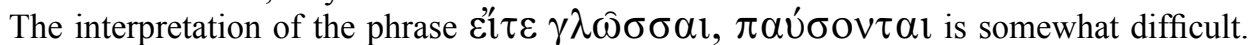
Some believe, taking the Middle Voice of the verb $\pi \alpha u$ oo $\sigma \tau \alpha$ l into consideration, that the gift of tongues will cease operation in some other way unlike the gifts of knowledge and prophecy. MacArthur says that the gift of tongues will disappear at a particular period. He links this period to the fall of Jerusalem and appearance of the New Testament books [6, p. 472-477]. Others dispute this point of view. Negrov writes: "It should not be understood, therefore, that Paul, by using the middle voice here, characterizes the cessation of tongues in a different way than he does the cessation of both the gift of prophecy and the gift of knowledge. $<\ldots>$ Paul's motive here is not to distinguish one gift from another in regard to their cessation but simply to claim, "Love never fails, but the practice of all gifts will one day cease" [17, p. 66-67].

Who is right then? All interpretations hold some truth. Both groups are correct: those, who direct their attention to the Middle Voice of the verb $\pi \alpha u ́ \sigma o v \tau \alpha l$ and those, who say that Paul had no intention to talk about the upcoming cessation of tongues as his main goal was to show superiority of love over the gifts. Most likely, Paul wanted to say that at the moment of personal encounter with God, every believer will receive a new knowledge and a new revelation from the Lord and the gift of tongues will cease as unnecessary. As we conclude the theme of spiritual gifts, we should say that spirituality is not about possession of gifts; it is, in essence, an understanding of one's purpose and gratitude to God for the gifts and their appropriate use.

Misunderstanding of the essence and purpose of spiritual gifts leads the church to separation. To achieve unity in the church, recognition of the authority of the Holy Spirit, 
submission to His will and readiness for His leadership are necessary. It is important to understand that every born-again Christian has a spiritual gift. This gift, by the will of God, was given to the benefit of both the Christian himself and the church. Not all Christians have the same gifts. But all the gifts are equally important. And those that are less visible are sometimes more important.

Purpose of gifts: glorifying God, caring for one another, evangelizing the gospel to people. The main condition for use is love, the benefit for each member and the Body of Christ as a whole, the necessity of God's guidance and the necessity of keeping a specified order for ministering with gifts set by God.

\section{References:}

1. Порублев Н.В. Феномен глоссалалии. Мельбурн, 1995. 72 с.

2. Bauer W.A. Greek-English Lexicon of the New Testament and Early Christian Literature / ed. : W.F. Arndt, F.W. Gingrich. 2 ed. Chicago ; London : The University of Chicago Press, 1979. $1188 \mathrm{p}$.

3. Louw J.P., Nida E.A. Greek-English Lexicon of the New Testament Based on Semantic Domains. 2 ed. Vol. 1, 2. New York : United Bible Society, 1989. 1200 p.

4. Роджерс К.Л. (мл.), Роджерс К.Л. (III). Новый лингвистический и экзегетический ключ к греческому тексту Нового Завета. Санкт-Петербург : Библия для всех, 2001. 988 с.

5. Wiersbe W.W. Be Wise. Russian Edition. Chicago : SGP, 1987. 300 p.

6. МакАртур Дж. Первое послание к Коринфянам: толкование. Киев : Киевская Духовная Семинария, 1993. 638 с.

7. Боор В. Вуппертальское изучение Библии. Первое послание к Коринфянам (Der erste Brief an die Korinther). Русское издание. Korntal : Licht im Osten, 1989. 500 c.

8. МакДональд В. Библейский комментарий для христиан. Новый Завет (BBC - Believer's Bible Commentary - New Testament). Русское издание. Bielefeld : Christliche LiteraturVerbreitung, 2000. $1506 \mathrm{c}$.

9. Hodge C. Commentary on the First Epistle to the Corinthians. Grand Rapids : Eerdmans Publishing Company, 1950. 350 p.

10. Gaffin R.B. "Life-giving spirit": Probing the center of Paul's Pneumatology. Journal of the Evangelical Theological Society. 1998. Vol. 41/4. P. 573-590.

11. Данн Дж. Единство и многообразие в Новом Завете. Москва : Библейско-богословский институт святого апостола Андрея Первозванного, 1997. 280 с.

12. Янкаала Е. Духовные дары (Spiritual Gifts). Санкт-Петербург : Библия для всех, 1996. $200 \mathrm{c}$.

13. The Full Life Study Bible. New Testament. Life Publishers International / ed. D.C. Stamps. Campbell : Springfield, 1997. 144 p.

14. Pfeiffer C.F., Harrison E.F. The Wycliffe Bible Commentary. Chicago : Moody Press, 1990. $1552 \mathrm{p}$.

15. White R.F. A comparison of Cessationist and Noncessationist Argumentation. Journal Evangelical Theological Society. 1992. Vol. 35/2. P. 173-181.

16. Fee G. The First Epistle to the Corinthians. Grand Rapids : Wm. B. Eerdmans, 1987. 1044 p.

17. Negrov A.I. The Centrality of Love in Paul's Theology of Spiritual Gifts: An Exegetical Study of 1 Corinthians : A Thesis Submitted to the Faculty of Biblical Studies in Partial Fulfillment of the Requirements for the Degree of Master of Arts in the New Testament. Saskatchewan: Caronport, 1995. 200 p. 


\title{
СВЯТИЙ ДУХ, ДУХОВНІ ДАРИ ТА СДНАННЯ ЦЕРКВИ: ГЕРМЕНЕВТИЧНО-ЕКЗЕГЕТИЧНА ЕКСКУРСІЯ В ГЛАВИ 12-14 ПЕРШОГО ПОСЛАННЯ АПОСТОЛА ПАВЛА ДО КОРИНТЯН
}

\author{
Олександр Шумілін \\ Бішкекський біблійний коледж \\ вул. Тверська, 42, 720080, Бішкек, Киргизстан
}

Статтю присвячено герменевтично-екзегетичному дослідженню глав 12-14 Першого послання апостола Павла до Коринтян. Саме ці глави оповідають про одну з причин поділу в коринтській громаді - різне розуміння членами громади призначення та використання духовних дарів церкви, особливо дару інших мов, а також гордості й пихи. У цих же розділах читач знаходить шлях до досягнення єдності. Показаний принцип неподільності церкви Божої, яку автор послання уподібнює людському тілу. У ньому всі члени рівні, кожен виконує свою роль та служить не стільки собі, скільки всьому тілу. Не видимі оком органи часом є набагато важливішими, ніж видимі.

У результаті дослідження джерела духовних дарів виявлено, хто та як отримує духовні дари, а також їх призначення, визначені головні умови використання дарів. Показано, що любов і бажання збудувати церкву своїм служінням за допомогою духовних дарів - це ті якості християнина, які стоять на першому місці. Правильне розуміння і Коринтянами, і сучасними християнами глав 12-14 послання та застосування на практиці духовних істин, викладених у них, слугуватиме збереженню єдності в помісній громаді й досягненню єдності між представниками різних християнських конфесій.

Відомо досить багато робіт, присвячених темі єдності церкви. Здебільшого дослідники брали за основу або інші глави Першого послання до Коринтян, або інші книги Біблії. Прикметна особливість цієї роботи - акцент саме на згаданих вище главах Першого послання до Коринтян, а також на виявленні ролі Святого Духа в розподілі духовних дарів і творенні єдності церкви.

Ключові слова: Святий Дух, духовні дари, єдність церкви, призначення духовних дарів, використання духовних дарів, дар інших мов. 